\title{
Extreme Air Pollution in Global Megacities
}

\author{
Miriam E. Marlier ${ }^{1,2} \cdot$ Amir S. Jina ${ }^{3}$ Patrick L. Kinney ${ }^{4} \cdot$ Ruth S. DeFries $^{1}$
}

Published online: 17 February 2016

(C) Springer International Publishing AG 2016

\begin{abstract}
Air quality in the world's most populous cities (megacities) impacts a sizeable proportion of the global population. Projected population increases in urban areas over the coming decades underscore the importance of understanding the sources, variations, and impacts of air pollution. While some megacities experience episodic extreme events, in others, extremely degraded air quality is chronic. In this review, we assess recent findings on the impacts of extreme air pollution, which we define as concentrations exceeding international guidelines. We highlight recent research on pollution and growth trends in the most populous megacities. We then emphasize important new methods for monitoring air pollution exposure, such as satellite-based estimates, and suggest future needs, including a more comprehensive understanding of the health and economic impacts. The primary conclusion to emerge is that, globally, while the extreme air pollution
\end{abstract}

This article is part of the Topical Collection on Extreme Events

Electronic supplementary material The online version of this article (doi:10.1007/s40641-016-0032-z) contains supplementary material, which is available to authorized users.

Miriam E. Marlier

mem2225@columbia.edu

1 Department of Ecology, Evolution and Environmental Biology, Columbia University, 1200 Amsterdam Ave., New York, NY 10027, USA

2 Department of Geography, University of California, Los Angeles, 1255 Bunche Hall, Los Angeles, CA 90095, USA

3 Department of Economics, University of Chicago, 5757 South University Ave., Chicago, IL 60637, USA

4 Mailman School of Public Health, Columbia University, 722 W. 168th St., New York, NY 10032, USA burden is highest in megacities in developing countries, significant gaps remain in our understanding.

Keywords Megacities $\cdot$ Air quality $\cdot$ Pollution $\cdot$

Environmental health

\section{Introduction}

Megacities are defined as urban agglomerations of more than 10 million people and have increased from 10 cities with a total of 153 million people in 1990 to 28 cities with a total of 453 million people in 2014 [1]. By 2030, the total population of megacities is projected to reach 730 million people in 41 cities (Fig. 1a) [1], highlighting the urgency to better understand the influence of these population centers on their surrounding environment and the well-being of residents. For example, ambient (outdoor) air pollution is a leading risk factor according to the Global Burden of Disease [3] with more than $96 \%$ of the global population in large cities exposed to fine particulate matter $\left(\mathrm{PM}_{2.5}\right)$ above World Health Organization (WHO) air quality standards [4]. While the 30 most populated urban areas account for $7 \%$ of the global burden from ambient air pollution (roughly equal to population share), several megacities in East and South Asia have higher per capita effects [5••]. The current knowledge base of air pollution in megacities is spread across multiple scales, ranging from global or regional assessments to individual megacities or specific locations within these cities.

Here, we review the recent literature describing extreme air pollution (sporadic or chronic) in global megacities. We primarily concentrate on $\mathrm{PM}_{2.5}$ and ozone $\left(\mathrm{O}_{3}\right)$ but also include research on other relevant pollutants, carbon monoxide (CO), volatile organic compounds (VOCs), and black carbon (BC). We focus on studies published since 2013 and megacities that are currently, or projected by 2030 , to rank in the top 10 for 



Fig. 1 a Population in the 30 most populous megacities for 2000-2030, with projected 2030 population indicated by darker colors and $\mathbf{b} \%$ population change from 2015 to 2030 for the 10 most populous cities in both years (given overlap, this amounts to 13 cities total) [2]

populations of the largest urban agglomerations defined by the U.N. World Urbanization Prospects. Given an overlap between the 2 years, this amounts to 13 megacities overall (Fig. 1b).

\section{Global Overview}

Recent estimates of the distribution of air quality are useful for understanding air pollution in megacities from a global perspective. Figure 2 shows the distribution of satellitederived $\mathrm{PM}_{2.5}$ over 2001-2010 (Fig. 1a) and the change in concentrations between the two timepoints (Fig. 1b) $[6,7 \bullet \bullet]$. From 1998 to 2012, the most prominent trends in monthly $\mathrm{PM}_{2.5}$ were in the Eastern United States $\left(-0.4 \mu \mathrm{g} / \mathrm{m}^{3} /\right.$ year), the Arabian Peninsula $\left(0.8 \mu \mathrm{g} / \mathrm{m}^{3} /\right.$ year $)$, South Asia $(0.9 \mu \mathrm{g} /$ $\mathrm{m}^{3} /$ year $)$, and East Asia $\left(0.8 \mu \mathrm{g} / \mathrm{m}^{3} /\right.$ year) [8]. Sources, and the extent to which they are produced locally or regionally, vary substantially and are dominated by residential energy usage in 



Fig. 2 Global average satellite-derived $\mathrm{PM}_{2.5}$ from 2001 to $2010(\mu \mathrm{g} /$ $\mathrm{m}^{3}$ ), including dust (top panel) and the change from 2001 to 2010 (bottom panel). 2001 and 2010 estimates were selected from datasets as the center

India, China, and Bangladesh; power generation in the USA; biomass burning in the tropics; agricultural burning across Europe and Russia; and dust in North Africa and the Middle East [5••, 9].

At the global scale, premature mortality estimates for the past decade range from 1.6-3.3 to $0.1-0.8$ million adult deaths per year from ambient $\mathrm{PM}_{2.5}$ and $\mathrm{O}_{3}$ exposure, respectively (Table 1) [5••, 9-12]. Over 1998-2012, satellite-based of a 3-year average (2000-2002 for 2001) [6, 7••]. Most populous megacities (defined for 2015 and 2030 projections) are indicated on the map

analysis indicates that global population-weighted $\mathrm{PM}_{2.5}$ has increased by $0.55 \mu \mathrm{g} / \mathrm{m}^{3}$, largely driven by increases in East and South Asia (3.2 and $2.9 \%$ /year) [7••]. Future projections estimate that the contribution of urban areas $(>400$ people/ $\mathrm{km}^{2}$ ) to global mortality from ambient pollution will increase from 60 to $65 \%$ of the total from 2010 to 2050 , driven partly by population increases but also by higher per capita mortality attributable to air pollution $[5 \bullet \bullet]$. 
Table 1 Recent global estimates of $\mathrm{PM}_{2.5}$ and $\mathrm{O}_{3}$-related health impacts for adults $\geq 30$ years. Causes of death are chronic obstructive pulmonary disease (COPD), cardiopulmonary disease (CPD), cerebrovascular disease (CeVD), ischemic heart disease (IHD), cardiovascular disease (CVD), respiratory disease (RD), all causes (AC), and lung cancer (LC)

\begin{tabular}{llll}
\hline Study & $\mathrm{PM}_{2.5}$ & $\mathrm{O}_{3}$ & Details \\
\hline Evans et al. [9] & $3.3 \mathrm{E} 6 \mathrm{AC}$ & Not studied & Satellite based for 2001-2006, not including dust \\
& $2.5 \mathrm{E} 6 \mathrm{CPD}$ & & \\
& $1.3 \mathrm{E} 6 \mathrm{IHD}$ & & \\
& $2.2 \mathrm{E} 5 \mathrm{LC}$ & & \\
& $2.0 \mathrm{E} 6 \mathrm{CPD}$ & $4.7 \mathrm{E} 5 \mathrm{RD}$ & Model based for 2000 vs. 1850 (pre-industrial) \\
Silva et al. [10] & $1.5 \mathrm{E} 5 \mathrm{LC}$ & & \\
& $1.5 \mathrm{E} 6 \mathrm{CPD}$ & $3.8 \mathrm{E} 5 \mathrm{RD}$ & Model based for 2000 vs. 1860 (pre-industrial) \\
Fang et al. [11] & $9.5 \mathrm{E} 4 \mathrm{LC}$ & & \\
& $2.0 \mathrm{E} 6 \mathrm{CVD}$ & $7.7 \mathrm{E} 5 \mathrm{RD}$ & Model based for $\sim 2005$ \\
Lelieveld et al. [12] & $1.9 \mathrm{E} 5 \mathrm{LC}$ & & \\
& $1.1 \mathrm{E} 6 \mathrm{IHD}$ & $1.4 \mathrm{E} 5 \mathrm{COPD}$ & Model based for $\sim 2010$ \\
Lelieveld et al. [5••] & $1.3 \mathrm{E} 6 \mathrm{CeVD}$ & & \\
& $3.7 \mathrm{E} 5 \mathrm{COPD}$ & & \\
& $1.6 \mathrm{E} 5 \mathrm{LC}$ & & \\
\end{tabular}

\section{How to Measure Extremes}

We define extremes relative to international and national air quality standards (Fig. S1). The $\mathrm{O}_{3}$ standard typically refers to the $8 \mathrm{~h}$ maximum because of strong diurnal variability in concentrations. $\mathrm{PM}_{2.5}$ and $\mathrm{PM}_{10}$ have standards for both $24 \mathrm{~h}$ and annual average concentrations. Though not explored here, air quality indicators are useful for communicating information to the public $[13,14]$.

Three primary, and complementary, methods to measure air pollution are ground-based monitors, satellite-based observations, and atmospheric models. First, ground-based data offers detailed air quality information at a point location; station locations should be optimized to best represent concentrations over a spatial domain [15]. Satellites can monitor air quality in areas outside of ground-based monitoring networks, such as in rural areas and/or developing countries [16]. Recent work has refined satellite estimates of surface-level $\mathrm{PM}_{2.5}$ (Fig. 2); satellite measurements of aerosol optical depth (AOD), including from Moderate Resolution Imaging Spectroradiometer (MODIS), Multi-angle Imaging SpectroRadiometer (MISR), and SeaViewing Wide Field-of-View Sensor (SeaWiFS), are converted from column observations to surface $\mathrm{PM}_{2.5}$ based on the vertical profile estimated by a chemical transport model (GEOS-Chem) $[6,7 \bullet \bullet, 17]$. In addition, new retrieval algorithms estimate MODIS AOD at a finer spatial resolution, which can help improve the relationship with surface $\mathrm{PM}_{2.5}$ [18]. Finally, atmospheric models are useful for understanding the contribution of individual sources [5••, 12] and interactions among atmospheric chemistry and climate [10]. However, the coarse spatial resolution of some global models can be challenging for estimating concentrations at smaller spatial scales [19].

Table 2 Recent estimates of pollution-related socioeconomic impacts

\begin{tabular}{|c|c|c|c|}
\hline Study & Outcome & Pollutant & Details \\
\hline Hanna and Oliva [23] & $\begin{array}{l}\text { Labor productivity } \\
\text { (hours worked) }\end{array}$ & Multiple & $\begin{array}{l}20 \% \text { decrease in pollution from a refinery closure resulted in a } 3.5 \% \\
\text { increase in hours worked per week }\end{array}$ \\
\hline $\begin{array}{l}\text { Graff Zivin and } \\
\text { Neidell }[24 \bullet \bullet]\end{array}$ & $\begin{array}{l}\text { Labor productivity } \\
\text { (quality of work) }\end{array}$ & $\mathrm{O}_{3}$ & $\begin{array}{l}10 \mathrm{ppb} \text { increase of } \mathrm{O}_{3} \text { decreases intensive margin productivity of } \\
\text { outdoor workers by } 5.5 \%\end{array}$ \\
\hline Adhvaryu et al. [25] & $\begin{array}{l}\text { Labor productivity } \\
\text { (quality of work) }\end{array}$ & $\mathrm{PM}_{2.5}$ & $\begin{array}{l}\text { Productivity effects among factory workers in Bangalore and evidence that } \\
\text { management decisions (in particular, task reassignment) may mitigate the effects }\end{array}$ \\
\hline Chang et al. [26] & $\begin{array}{l}\text { Labor productivity } \\
\text { (quality of work) }\end{array}$ & $\mathrm{PM}_{2.5}$ & $\begin{array}{l}\mathrm{PM}_{2.5} \text { decreases productivity for indoor workers. Labor cost savings due to } \\
\text { pollution reductions from } 1999 \text { to } 2008 \text { in the USA is nearly one third of the total } \\
\text { benefit (inclusive of health effects) }\end{array}$ \\
\hline Lavy et al. [27] & Cognitive performance & $\mathrm{PM}_{2.5}$ & $\begin{array}{l}\mathrm{PM}_{2.5} \text { leads to decreased cognitive performance on the day of exposure. Long-term } \\
\text { consequences by affecting performance on high-stake college admission exams, } \\
\text { leading to lower wages in adulthood }\end{array}$ \\
\hline Isen et al. [28••] & $\begin{array}{l}\text { Earnings and labor force } \\
\text { participation at age } 30\end{array}$ & TSP & $\begin{array}{l}\text { Exposure to pollution at birth in the USA is significantly related to lower earnings } \\
\text { and labor force participation at age } 30\end{array}$ \\
\hline Bharadwaj et al. [29] & Cognitive performance & $\mathrm{CO}$ & Exposure in utero leads to a decrease in test scores 10 years later (in Santiago, Chile) \\
\hline
\end{tabular}




\section{Impacts}

The main focus of research on impacts has been upon health outcomes, typically due to long-term exposure to pollution. New integrated exposure-response models aim to include higher concentrations of annual $\mathrm{PM}_{2.5}$ as found in Asia and the Middle East [20]. Individualized exposure assessments for California adults confirm prior relationships with $\mathrm{PM}_{2.5}$ and expand on $\mathrm{O}_{3}$ and $\mathrm{NO}_{2}$ effects on premature mortality [21]. In addition, Farmer et al. [22] reviewed how early-life exposure (in utero and childhood) can affect cardiopulmonary health later in life.

Additionally, several economically important sub-clinical impacts-i.e., not requiring hospitalization or treatmenthave been studied, including labor productivity and cognition (Table 2). This work has seen rapid development in recent years due to the increasing availability of high-frequency and spatially refined pollution data. Effects are both contemporaneous, usually short-term responses to daily variations in exposure, and long-term due to in utero exposure (see Almond and Currie [30] for a review). The labor studies find that pollution decreases productivity at both extensive margin (number of hours) and intensive margin (productivity while at work). Much of this research is drawn from empirical studies in developed countries, and estimated costs are substantial (e.g., Chang et al. [26] estimated labor cost savings due to pollution reductions from 1999 to 2008 in the USA as nearly one third of the total benefit). It is likely that costs in developing countries would be higher, with higher pollution levels and more people employed in high-risk activities (i.e., outdoor work or manufacturing). The impacts on cognition, both contemporaneously and in utero, suggest that human capital, an important factor of economic growth and well-being, is being negatively affected by pollution exposure (also see Graff Zivin and Neidell [24••]).

\section{Air Pollution in the Most Populous Megacities}

In the following sections, we examine air pollution concentrations in the most populous global megacities. In Fig. 3, we compare maximum daily concentrations (from stations) and annual average concentrations (from stations and satellites) with air quality standards. Although these data sources represent a point measurement versus a citywide average, they are useful to gauge chronic and episodic extreme pollution.

Megacities differ with regards to their geographic location, pollution sources, and development status, but one way to identify and assess potential strategies to improve air quality is by examining the factors contributing to current severe air quality situations with other large cities that have battled extreme pollution [32]. In developing countries, pollution tends to increase with per capita income (Fig. 4),
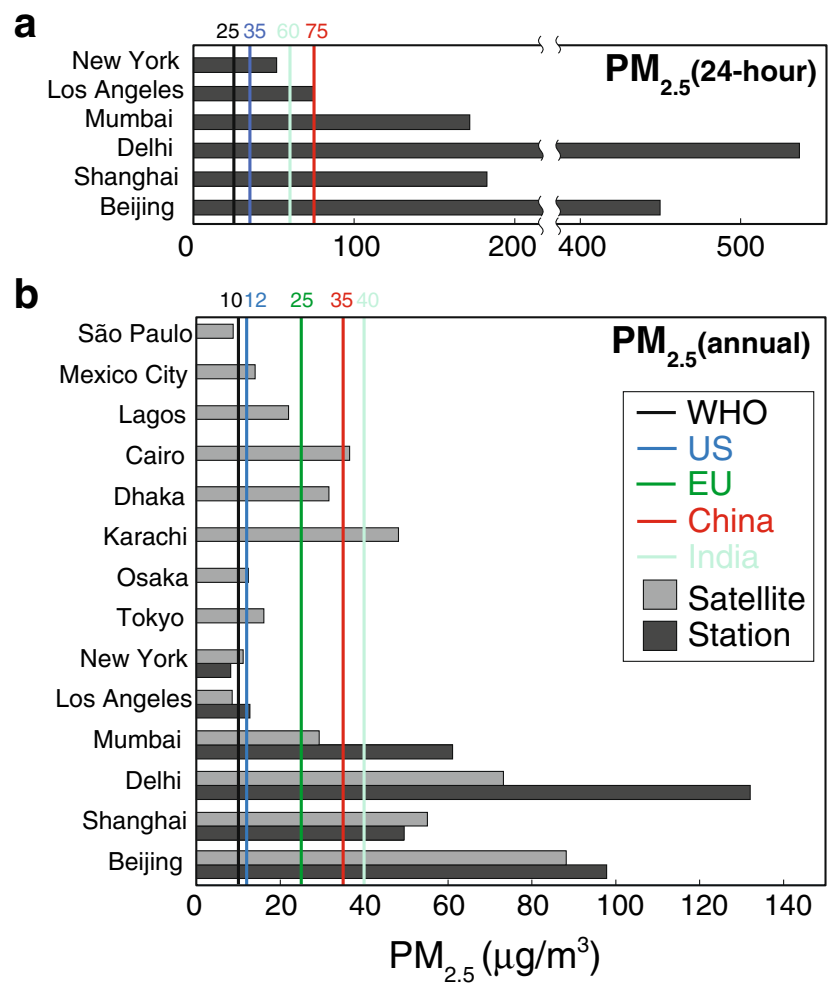

Fig. 3 a Maximum 24-h $\mathrm{PM}_{2.5}$ concentrations $\left(\mu \mathrm{g} / \mathrm{m}^{3}\right)$ recorded in 2014 at USA Embassy locations in Mumbai, Delhi (http://newdelhi. usembassy.gov/airqualitydataemb.html), Shanghai, and Beijing (http:// www.stateair.net/) and USA E.P.A. sites in Los Angeles and New York (http://www3.epa.gov/airquality/airdata/ad_rep_frmvfem.html). Measurements provided by the USA Department of State Embassy locations are not fully verified or validated. Lines correspond to daily standards (Fig. S1). b Annual average $\mathrm{PM}_{2.5}$ concentrations $\left(\mu \mathrm{g} / \mathrm{m}^{3}\right)$ based on stations (for 2014) and satellite data (for 2011) [6, 7••]. Areaweighted averages are taken over cities, with spatial extents derived from the GRUMP dataset [31] and restricted to a contiguous area within $0.5^{\circ}$ radius around the UN-specified urban centroid. Lines correspond to annual standards (Fig. S1)

driven by increasing manufacturing output and demand for private transport and electricity [33]. Much of the expected urban growth is expected in developing countries, places often associated with comparatively weaker institutional settings to create and enforce strong environmental regulations and uncertainty about their growth path of megacities. It is also important to note global and regional factors that contribute to air pollution, like international trade and the movement of manufacturing to low-wage developing countries (for example, as industry moved from the USA to China, air quality in the USA improved while it worsened in China) [34], though technological improvements have also greatly reduced pollution in advanced economies [35]. The following review of studies is organized by country, given the influence that regional pollution can have on urban air quality and the transport of pollution from urban areas to a broader region. 
Fig. 4 2001-2010 average $\mathrm{PM}_{2.5}$ $[6,7 \bullet \bullet]$ versus national GDP for the 13 cities shown in Fig. 1b, with each city represented by population size. $\mathrm{PM}_{2.5}[6,7 \bullet \bullet]$ was extracted for a $100-\mathrm{km}$ buffer around each urban agglomeration. The shaded area is the $95 \%$ confidence interval around the quadratic fitted line. GDP data from World Bank Development Indicators; $P P P$ purchasing power parity adjusted



\section{China}

China's most populous megacities, Shanghai and Beijing, are expected to increase from 23.7 to 30.8 million and from 20.4 to 27.7 million, respectively, between 2015 and 2030 [2]. The relationship between economic development and air quality in China's largest cities has followed the inverted-U shape of an environmental Kuznets curve for the past several decades [36], with pollution-related mortality highest in the megacities of Beijing, Shanghai, and the Pearl River area [5••].

Several recent studies have quantified extreme air pollution across China. For example, Rohde and Muller [37•] compiled hourly station data from 1500 sites in 2014, finding that $92 \%$ of Eastern China's population experienced more than $120 \mathrm{~h}$ of unhealthy air $\left(>150 \mu \mathrm{g} / \mathrm{m}^{3} \mathrm{PM}_{2.5}\right)$ with almost no areas in attainment of US standards $\left(12 \mu \mathrm{g} / \mathrm{m}^{3}\right.$ annual $\left.\mathrm{PM}_{2.5}\right)$. Population-weighted average $\mathrm{PM}_{2.5}$ exposure was $52 \mu \mathrm{g} / \mathrm{m}^{3}$, corresponding to 1.6 million/deaths per year (17\% of all deaths in China). For a long-term perspective, analysis of extreme visibility as a proxy for air pollution shows that the frequency of good visibility (low pollution) has decreased in all cities since 1960, especially after 1980 in large cities [38]. Despite decreasing visibility, satellite studies in East Asia show the increasing trend in $\mathrm{CO}_{2}$ emissions outweighing $\mathrm{NO}_{x}$ emissions, which suggests cleaner technologies [39]. However, since surface $\mathrm{O}_{3}$ production depends on $\mathrm{NO}_{2}$ and $\mathrm{VOC}$ emissions and $\mathrm{NO}_{2}$ has decreased in Shanghai and Beijing over the past decade, Jin and Holloway [40] found that $\mathrm{O}_{3}$ production efficiency has increased as it is no longer characterized by VOC-limited conditions.

In Beijing, several recent studies have analyzed the extreme haze of early 2013. Many of these haze events have similar vehicular and industrial sources, but different meteorological conditions, including stagnant weather, strong winds, and temperature inversions [41]. For example, a January 2013 haze event was mostly driven by surface emissions, but uncontrollable meteorological parameters such as sustained weak winds, high relative humidity, and a thick temperature inversion further promoted $\mathrm{PM}_{2.5}$ accumulation [42]. Beijing and Shanghai had mean daily $\mathrm{PM}_{2.5}$ concentrations during the haze event of 299.2 and $180.8 \mu \mathrm{g} / \mathrm{m}^{3}$, well above national and international standards [43]. In addition, $\mathrm{O}_{3}$ concentrations increased by 2.6 ppb per year over 2005 2011 despite air pollution control measures, linked to increases in VOC precursors and regional transport [44]. Jacobson et al. [45] studied the impact of urbanization around Beijing and found that physical changes (including surface albedo, temperature, and relative humidity) have induced meteorological changes which, holding other factors constant, have decreased $\mathrm{PM}$ and $\mathrm{NO}_{x}$ and increased $\mathrm{O}_{3}$.

For Shanghai, in addition to the impact of haze events mentioned previously, hourly surface $\mathrm{O}_{3}$ concentrations from 2010 to 2013 exceeded national standards (Fig. S1) and were linked to regional VOC transport, enhanced precursor concentrations, and industrial sources [46]. $\mathrm{O}_{3}$ production within and outside of Shanghai is under VOC-limited conditions because of coal use and wind direction, which is important for implementing control strategies [47].

\section{Japan}

Tokyo is the most populous megacity in the world but is expected to decrease from 38.0 to 37.2 million from 2015 to 2030. Similarly, Osaka will decline slightly from 20.2 to 20.0 million and will no longer be ranked among the top 10 of global megacities [2]. Despite the large populations, both megacities have some of the lowest current and projected levels of mortality from ambient air pollution (Fig. 5) [5••].

\section{India}

India contains two megacities ranked within the top 10 and several others above 10 million. The populations in Delhi and 
a

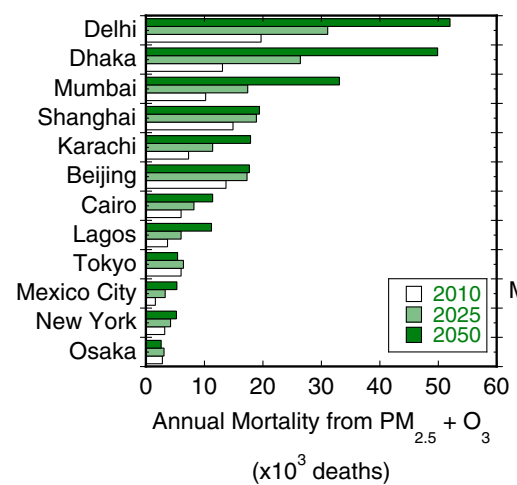

Fig. 5 Estimates by Lelieveld et al. [5 • $]$ of a annual combined mortality from $\mathrm{PM}_{2.5}$ and $\mathrm{O}_{3}\left(\times 10^{3}\right.$ deaths $)$ in the most populous megacities (ranked by population) for 2010, 2025, and 2050; b total population; and $\mathbf{c}$ per capita mortality. Future estimates from a BAU growth

Mumbai are expected to increase from 25.7 to 36.1 million and from 21.0 to 27.8 million, respectively, between 2015 and 2030 [2], along with large increases in air pollution impacts in the absence of control measures (Fig. 5). The most common emission sources are vehicles, manufacturing, electricity generation, construction, road dust, waste burning, household combustion, and sea salt [48•]. From 2010 to 2011, 111 coal-fired power plants across India contributed to estimated $80,000-115,000$ premature deaths and 20 million asthma cases [49]. Modeling of BC over India has found the importance of both local and non-local sources in contributing to concentrations [50], reiterating that air quality is not a solely local problem and is implicated in regional air pollution resulting in agricultural yield losses [51].

In Delhi, station-based $\mathrm{PM}_{2.5}$ analysis found $69 \%$ of samples exceeding 24-h standards [52]. Over 2008-2011, Delhi's $\mathrm{PM}_{2.5}$ and $\mathrm{PM}_{10}$ averaged 123 and $208 \mu \mathrm{g} / \mathrm{m}^{3}$ (above standards; Fig. S1) [53]. In October 2010, mean $\mathrm{PM}_{2.5}$ and $\mathrm{PM}_{10}$ concentrations were measured at 111 and $238 \mu \mathrm{g} / \mathrm{m}^{3}$, respectively, and hourly $\mathrm{O}_{3}$ concentrations occasionally above $100 \mathrm{ppb}$ [54]. Marrapu et al. [54] found that multiple emission sources from transportation, domestic, and industrial categories contributed to pollution in Delhi but also that pollutant sources from outside of Delhi contribute significantly to PM $(25 \%)$ and daytime $\mathrm{O}_{3}(60 \%)$. Tiwari et al. [55] measured 2010-2011 $\mathrm{PM}_{2.5}$ and confirmed concentrations exceeding standards, while noting strong variations diurnally, by day of the week, and with meteorology. Satellite observations of CO, an important $\mathrm{O}_{3}$ precursor, indicated that Delhi was the only megacity (out of eight examined) that exhibited an increase over 2000-2008 [56].

\section{Bangladesh}

The population in Dhaka is currently 17.6 million and ranked 11 th globally, but with 27.4 million by 2030, it would rank 6 th scenario that drives changes in both population and emission sources as described in Lelieveld et al. [5••]. Cities are ranked by highest estimated mortality for 2050 . Note that São Paulo was not included in this analysis

[2]. MODIS AOD observations show maximum values during the pre-monsoon season [57]. There is higher $\mathrm{CO}, \mathrm{O}_{3}$, and $\mathrm{CO}_{2}$ in western Bangladesh because of combined meteorology and emission influences but higher $\mathrm{NO}_{2}$ over Dhaka [58].

PM concentrations in Dhaka are much higher than national air quality standards $\left(15 \mu \mathrm{g} / \mathrm{m}^{3} \mathrm{PM}_{2.5}\right.$ and $\left.50 \mu \mathrm{g} / \mathrm{m}^{3} \mathrm{PM}_{10}\right)$, with mean observed values from 1996 to 2011 of $37 \mu \mathrm{g} / \mathrm{m}^{3}$ $\mathrm{PM}_{2.5}$ and $98 \mu \mathrm{g} / \mathrm{m}^{3} \mathrm{PM}_{10}$, dominated by emissions from the brick kiln industry [59]. Source apportionment studies have found that in Dhaka, almost $70 \%$ of $\mathrm{PM}_{2.5}$ is from anthropogenic sources, with a decline in vehicle emissions over 2010 2012 likely due to government policies [60]. Implementing cleaner brick kiln technologies in the Greater Dhaka region would have an estimated cumulative health cost savings for 2015-2020 between \$126 and 234 million [61].

\section{Pakistan}

Karachi is expected to grow from 16.6 to 24.8 million by 2030 [2]. A recent study based on mobile monitoring from 2007 to 2009 found the highest pollution levels in the winter season. Although mean monthly $\mathrm{CO}$ and $\mathrm{O}_{3}$ were below Pakistan's national air quality standards $\left(5 \mathrm{mg} / \mathrm{m}^{3} 8\right.$-h maximum $\mathrm{CO}$ and $180 \mu \mathrm{g} / \mathrm{m}^{3}$ 1-h maximum $\mathrm{O}_{3}$ ), concentrations of $\mathrm{CO}, \mathrm{O}_{3}$, $\mathrm{NO}_{x}$, and hydrocarbons have generally been increasing over time [62].

\section{Egypt}

The population in Cairo is estimated at 18.8 million in 2015 and is expected to rise to 24.5 million by 2030 [2]. Lelieveld et al. [63] found declines since 2010 in $\mathrm{NO}_{2}$ as measured by satellite, likely linked to political instability [63]. At longer time scales, model simulations suggest increasing $\mathrm{O}_{3}$ formation by 2050 that could push Cairo further above air quality 
standards during summer months, including extreme values above $100 \mathrm{ppb}$ [64].

\section{Nigeria}

Lagos is currently ranked outside of the top 10 with 13.1 million but will move to 9th globally with an expected 24.2 million people by 2030 [2]. A recent review lists air pollution sources from dump sites, open incinerators, power generation, vehicles, and industry while urging routine monitoring and air quality standards [65].

\section{Mexico}

Mexico City is expected to grow from 21.0 to 23.9 over the next 15 years [2]. Lei et al. [66] studied the impact of biomass burning on air quality and found little impact on $\mathrm{O}_{3}$ but more substantial increases with respect to organic aerosols and elemental carbon. The main contributors to VOC emissions $\left(\mathrm{O}_{3}\right.$ precursors) were vehicles and solvent-related industrial sources [67]. Regarding air pollution impacts, differences between individual exposure estimates and fixed monitoring stations were assessed with heart rate variability and traffic pollution exposure [68]. A recent analysis of infant mortality and pollution in Mexico City found that a $1 \%$ increase in annual $\mathrm{PM}_{10}$ and $\mathrm{CO}$ increases infant mortality by 0.4 and $0.3 \%$, respectively [69].

\section{Brazil}

The population in São Paulo is currently 21.1 million with expected growth to 23.9 million by 2030 [2]. Over 20102013, there were slight decreases in the contribution of vehicle emissions to $\mathrm{NO}_{x}, \mathrm{CO}$, and $\mathrm{PM}_{10}$, but increases in $\mathrm{O}_{3}$ [70]. Reddington et al. [71] estimated the contribution of deforestation to extreme air pollution in the region and found that a $30 \%$ reduction in fire-related $\mathrm{PM}_{2.5}$ prevented $400-1700$ premature adult deaths.

\section{USA}

18.6 million people live in New York City, and it is ranked 10th in population among global megacities but will fall to 14th by 2030 with 19.9 million [2]. Data available from the U.S. E.P.A. show annual average $\mathrm{PM}_{2.5}$ declining from 17 to $9 \mu \mathrm{g} / \mathrm{m}^{3}$ over $2000-2014$ and $\mathrm{O}_{3}$ from 106 to $72 \mathrm{ppb}$ from 1990 to 2014 (http://www3.epa.gov/airtrends). However, one recent study has highlighted the importance of spatial gradients of air pollutants for local air quality management [72].

\section{Other}

Here, we briefly discuss recent studies of megacities in regions underrepresented by the discussion above. As in New York City, air quality in downtown Los Angeles has improved with annual average $\mathrm{PM}_{2.5}$ declining from 22 to $12 \mu \mathrm{g} / \mathrm{m}^{3}$ over 2000-2014 and $\mathrm{O}_{3}$ declining from 115 to $72 \mathrm{ppb}$ from 1990 to 2014 (http://www3.epa.gov/airtrends). Pollack et al. [73] quantified $\mathrm{O}_{3}$ trends in Los Angeles from 1960 to 2010 and found a decline linked to decreases in VOC emissions. $\mathrm{NO}_{x}$, an $\mathrm{O}_{3}$ precursor, needs to be more strictly controlled. VOC emissions in Los Angeles and Paris indicated that traffic dominates urban anthropogenic emissions, unlike what emission inventories suggest, which has implications for accurately modeling $\mathrm{CO}$, aerosols, and $\mathrm{O}_{3}$ [74]. Similarly, a modeling study in Paris found a large underestimate in organic aerosols in the winter that is missed by current emission inventories [75]. In Paris, regional sources contributed $70 \%$ to fine PM, indicating that air quality improvement must focus on both local and regional sources [76]. Moscow experienced extreme pollution during August 2010 due to large-scale wildfires in forests and peatlands around the city [77].

\section{Air Pollution Policy}

Air pollution in megacities is a global, regional, and local issue. The relationship between global climate change and air pollution, the regional transport of pollutants over long distances and across political boundaries, and the effectiveness of pollution reduction policies are all current and future research areas. Currently, air pollution policies have largely been enacted at the level of countries or individual cities. In this section, we provide an overview of policy concerns at each of these scales, ending with a discussion of policy evaluations at local scales.

From a global perspective, there is the potential for substantial co-benefits from reducing pollutants that contribute both to degraded air quality and climate change, such as $\mathrm{PM}_{2.5}$ and $\mathrm{O}_{3}$ [78]. West et al. [79] found that global greenhouse gas mitigation would avoid $0.5 \pm 0.2$ million deaths by 2030 due to $\mathrm{PM}_{2.5}$ and $\mathrm{O}_{3}$ exposure, with the highest cobenefits (10-70 times the cost) in East Asia. These local health benefits can offer support for greenhouse gas reduction policies. However, this can be complicated by competing effects of different pollutants: for example, sulfate and $\mathrm{BC}$ aerosols have cooling and warming effects on climate, respectively, so air quality improvements from sulfate reductions can unmask warming. In addition, reductions of short-lived climate forcers, such as methane (an $\mathrm{O}_{3}$ precursor) and aerosols may result in smaller reductions in near-term warming than previously suggested [80]. Regardless, different mitigation 
scenarios can be evaluated for their combined benefits for climate, regional temperature and precipitation, and air quality [81]. Climate change can also impact air pollution, with ambient $\mathrm{O}_{3}$ concentrations expected to increase in the USA due to near-term climate change $[82,83]$. Accumulation of pollutants in stagnation events is expected to increase, especially in India, Mexico, and the Western United States [84]. For a more comprehensive discussion of interactions between air quality and climate change, we direct the reader to recent reviews by Fiore et al. [85] and Baklanov et al. [86].

Air quality is also a regional issue. Pollution is not confined to within the boundary of a megacity, instead many megacities have more exposure outside than inside of city boundaries [87]. At broader scales, Anenberg et al. [88] found that 3$7 \%$ of the health benefits from $\mathrm{PM}_{2.5}$ reductions in major industrial regions are due to inter-continental pollution transport. Kim et al. [89] used the GEOS-Chem adjoint model to calculate the sensitivities of population centers to regional fire sources. One related regional pollution policy is Singapore's Transboundary Haze Pollution Act, which addresses how fires in Indonesia can degrade air quality throughout Equatorial Asia [90].

In the following paragraphs, we outline several studies that evaluate the main types of policies associated with improving air quality, including direct regulation of emissions, cap and trade, taxation, congestion pricing, and promotion of mass transit. Private actions unrelated to policies are often taken to reduce exposure.

Greenstone and Hanna [91] assessed the impact of India's environmental regulations on measured air pollution, finding substantial air quality improvements with suggestive evidence that public support for environmental improvements partly compensates for a weaker institutional setting. Duflo et al. $[92 \cdot 0]$ offered a promising policy solution to improve monitoring and compliance with environmental policies in developing countries - a system of third party auditors in India dramatically improved compliance and significantly reduced pollution.

A number of megacities have pursued driving restrictions in order to combat both congestion and pollution. Viard and $\mathrm{Fu}$ [93] evaluated a policy in Beijing, finding a decrease in both $\mathrm{PM}_{10}$ (between 18 and $21 \%$ ) and labor supply as it increases commuting costs. Other transportation policies, like mass transit, show promise for decreasing environmental pollution. Goel and Gupta [94] found that the construction of the Delhi Metro reduced CO locally by $34 \%$.

It is likely that policies for cleaner air will have numerous direct economic benefits to individuals. Deschenes et al. [95] estimated the amount saved in protective investments after the implementation of the US $\mathrm{NO}_{x}$ Budget Trading Program, finding a $\sim \$ 1.8$ billion reduction in protective measures due to cleaner air. However, there are also potentially negative aspects of private demand for cleaner environments, as Zheng et al. [96] showed how the means to invest in protective measures like air filters in richer households in Beijing can be associated with decreases in support for strong policies and increases in inequality of pollution impacts. Other policies may have unintended consequences for air pollution; for example, Chen et al. [97] noted that a policy of subsidizing heating north of China's Huai River has led to a decrease of 5.5 years of life expectancy. Aside from directed policies, economic factors such as energy prices and macroeconomic fluctuations are important considerations. Cesur et al. [98] found that a boom in natural gas decreased infant mortality in Turkey, and Heutel and Ruhm [99] pointed to macroeconomic fluctuations as an important source of uncertainty in projecting forward the costs of pollution.

\section{Future Research Directions and Conclusions}

The previous sections suggest much-needed research directions to keep air pollution below recommended limits; future population increases in developing countries and the changing baseline incidence of disease will increase health impacts even if concentrations were to remain constant [100]. We stress that there are several severely understudied megacities, especially in Africa and South Asia. As shown in Fig. 3, monitoring data is not readily available for several megacities, making comparisons difficult.

Regarding air pollution monitoring, although new tools are available, the examination by Ford and Heald [101] of satellite versus modeled $\mathrm{PM}_{2.5}$ exposures emphasizes the need to resolve uncertainties among different methodologies. This is important not just for estimating current health effects of air pollution in megacities but also for projecting future changes.

For estimating health impacts, concerns have been raised that the dose-response function that is typically used to estimate mortality from pollution may not be applicable in developing countries with higher pollution levels. Pope et al. [102] suggested that non-linearities may exist in the dose-response curve at higher pollution levels, and this could substantially change mortality calculations; Arceo et al. [69] found suggestive evidence for this in Mexico City. In addition, health estimates could also be routinely underestimating mortality if toxicity is higher for certain particles, such as carbonaceous particles [5••]. Cohort studies currently underway in China may help to resolve this issue in the future.

As understanding of the set of air pollution impacts grows, an important area of research will be to take a more integrated or holistic approach to evaluating these impacts on society, as effective policy-making requires accurate cost-benefit analyses. There is a need to address the full cost of pollution from megacities, including techniques to value mortality and morbidity costs, integrating these costs with valuations from nonhealth impacts discussed above and expanding the set of 
researched impacts. Where possible, empirical evaluations of these impacts should guide policy. As many of the above papers suggest, integrating across impacts may substantially increase the societal costs of air pollution compared to evaluations examining only mortality.

The trajectory of growth of megacities is another important research area. We see that pollution tends to increase with income up to a point and that richer countries, on average, have lower pollution (Fig. 4). It is unclear how the relative rates of pollution abatement, population growth, and economic growth will affect the projected population exposure as megacities continue to grow, particularly in Asia and Africa. Migration to urban areas is expected to change emissions and exposure patterns, as observed in Beijing with different energy consumption patterns between rural residents, migrants, and urban residents [103]. Finally, although the populations within the immediate vicinity of megacities often experience the highest pollution, it becomes a global issue when we consider the links between local air pollution and greenhouse gas concentrations as well as transport of pollution in and out of megacities. At the same time, local demand for cleaner air could also spur greenhouse gas mitigation. This two-way linkage is another promising area of research.

While the recent papers discussed here motivate these new research directions, they also show that it is possible for megacities to reduce extreme air pollution. Some of the world's most populous megacities have some of the lowest pollution concentrations, and the lessons learned in these cities can serve as guiding principles in our increasingly urbanized world.

Acknowledgments We thank the Winslow Foundation for the support of this work. We also acknowledge the U.S. Department of State and U.S. Environmental Protection Agency for providing access to station data.

\section{Compliance with Ethical Standards}

Conflict of Interest On behalf of all authors, the corresponding author states that there is no conflict of interest.

\section{References}

Papers of particular interest, published recently, have been highlighted as:

- Of importance

•. Of major importance

1. World Urbanization Prospects: the 2014 revision (ST/ESA/ SER.A/366). United Nations, Department of Economic and Social Affairs, Population Division; 2015.
2. World Urbanization Prospects: the 2014 revision, CD-ROM edition. United Nations, Department of Economic and Social Affairs, Population Division; 2014.

3. Lim SS, Vos T, Flaxman AD, Danaei G, Shibuya K, Adair-Rohani $\mathrm{H}$, et al. A comparative risk assessment of burden of disease and injury attributable to 67 risk factors and risk factor clusters in 21 regions, 1990-2010: a systematic analysis for the Global Burden of Disease Study 2010. Lancet. 2012;380:2224-60.

4. Krzyzanowski M, Apte JS, Bonjour SP, Brauer M, Cohen AJ, Prüss-Ustun AM. Air pollution in the mega-cities. Curr Environ Health Rep. 2014;1:185-91.

5.• Lelieveld J, Evans JS, Fnais M, Giannadaki D, Pozzer A. The contribution of outdoor air pollution sources to premature mortality on a global scale. Nature. 2015;525:367-71. Global overview of current and future impacts of air pollution on mortality, including estimates for megacities.

6. van Donkelaar A, Martin RV, Brauer M, Boys BL. Global annual $\mathrm{PM}_{2.5}$ grids from MODIS, MISR and SeaWiFS Aerosol Optical Depth (AOD), 1998-2012 [Internet]. Palisades, NY: NASA Socioeconomic Data and Applications Center (SEDAC); 2015. Available from: doi: 10.7927/H4028PFS. Accessed 15 Oct 2015.

7.•• van Donkelaar A, Martin RV, Brauer M, Boys BL. Use of satellite observations for long-term exposure assessment of global concentrations of fine particulate matter. Environ Health Perspect. 2015;123:135-43. Describes new methodology for deriving surface-level $\mathbf{P M}_{2.5}$ from satellite observations.

8. Boys BL, Martin RV, van Donkelaar A, MacDonell RJ, Hsu NC, Cooper MJ, et al. Fifteen-year global time series of satellitederived fine particulate matter. Environ Sci Technol. 2014;48: 11109-18.

9. Evans J, van Donkelaar A, Martin RV, Burnett R, Rainham DG, Birkett NJ, et al. Estimates of global mortality attributable to particulate air pollution using satellite imagery. Environ Res. 2013;120:33-42.

10. Silva RA, West JJ, Zhang Y, Anenberg SC, Lamarque J-F, Shindell DT, et al. Global premature mortality due to anthropogenic outdoor air pollution and the contribution of past climate change. Environ Res Lett. 2013;8:034005.

11. Fang Y, Naik V, Horowitz LW, Mauzerall D. Air pollution and associated human mortality: the role of air pollutant emissions, climate change and methane concentration increases from the preindustrial period to present. Atmos Chem Phys. 2013;13:1377-94.

12. Lelieveld J, Barlas C, Giannadaki D, Pozzer A. Model calculated global, regional and megacity premature mortality due to air pollution. Atmos Chem Phys. 2013;13:7023-37.

13. de Sherbinin A, Levy MA, Zell E, Weber S, Jaiteh M. Using satellite data to develop environmental indicators. Environ Res Lett. 2014;9:084013.

14. Hsu A, Reuben A, Shindell D, de Sherbinin A, Levy M. Toward the next generation of air quality monitoring indicators. Atmos Environ. 2013;80:561-70.

15. Araki S, Iwahashi K, Shimadera H, Yamamoto K, Kondo A. Optimization of air monitoring networks using chemical transport model and search algorithm. Atmos Environ. 2015;122:22-30.

16. Prud'homme G, Dobbin NA, Sun L, Burnett RT, Martin RV, Davidson A, et al. Comparison of remote sensing and fixed-site monitoring approaches for examining air pollution and health in a national study population. Atmos Environ. 2013;80:161-71.

17. van Donkelaar A, Martin RV, Spurr RJD, Drury E, Remer LA, Levy $\mathrm{RC}$, et al. Optimal estimation for global ground-level fine particulate matter concentrations. J Geophys Res Atmos. 2013;118:5621-36.

18. Chudnovsky AA, Kostinski A, Lyapustin A, Koutrakis P. Spatial scales of pollution from variable resolution satellite imaging. Environ Pollut. 2013;172:131-8. 
19. Stock ZS, Russo MR, Pyle JA. Representing ozone extremes in European megacities: the importance of resolution in a global chemistry climate model. Atmos Chem Phys. 2014;14: 3899-912.

20. Burnett RT, Pope CAI, Ezzati M, Olives C, Lim SS, Mehta S, et al. An integrated risk function for estimating the global burden of disease attributable to ambient fine particulate matter exposure. Environ Health Perspect. 2014;122:397-403.

21. Jerrett M, Burnett RT, Beckerman BS, Turner MC, Krewski D, Thurston G, et al. Spatial analysis of air pollution and mortality in California. Am J Respir Crit Care Med. 2013;188:593-9.

22. Farmer SA, Nelin TD, Falvo MJ, Wold LE. Ambient and household air pollution: complex triggers of disease. Am J Physiol Heart Circ Physiol. 2014;307:H467-76.

23. Hanna R, Oliva P. The effect of pollution on labor supply: evidence from a natural experiment in Mexico City. J Public Econ. 2015;122:68-79.

24.• Graff Zivin J, Neidell M. Environment, health, and human capital. J Econ Lit. 2013;51:689-730. One of the first demonstrations of labor impacts of pollution, which has led to a number of other papers that contribute substantially to the analysis of the costs of pollution.

25. Adhvaryu A, Kala N, Nyshadham A. Management and shocks to worker productivity: evidence from air pollution exposure in an Indian garment factory. Working Paper. 2014.

26. Chang T, Graff Zivin J, Gross T, Neidell M. Particulate pollution and the productivity of pear packers. NBER Working Paper No. 19944. 2014.

27. Lavy V, Ebenstein A, Roth S. The long run human capital and economic consequences of high-states examinations. NBER Working Paper No. 20647. 2014.

28.• Isen A, Rossin-Slater M, Walker WR. Every breath you takeevery dollar you'll make: the long-term consequences of the Clean Air Act of 1970. NBER Working Paper No. 19858. 2014. Identifies pollution impacts on the long-run determinants of earnings and employment, which constitute an ongoing cost to society and are likely larger in developing countries.

29. Bharadwaj P, Gibson M, Zivin J, Neilson C. Gray matters: fetal pollution exposure and human capital formation. NBER Working Paper No. 20662. 2014.

30. Almond D, Currie J. Killing me softly: the fetal origins hypothesis. J Econ Perspect. 2011;25:153-72.

31. Balk DL, Deichmann U, Yetman G, Pozzi F, Hay SI, Nelson A. Determining global population distribution: methods, applications and data. Parasitology. 2006;62:119-56.

32. Zhang D, Liu J, Li B. Tackling air pollution in China-what do we learn from the great smog of 1950s in London. Sustainability. 2014;6:5322-38.

33. Zheng S, Kahn ME. Understanding China's urban pollution dynamics. J Econ Lit. 2013;51:731-72.

34. Lin J, Pan D, Davis SJ, Zhang Q, He K, Wang C, et al. China's international trade and air pollution in the United States. Proc Natl Acad Sci U S A. 2014;111:1736-41.

35. Levinson A. A direct estimate of the technique effect: changes in the pollution intensity of US manufacturing, 1990-2008. J Assoc Environ Resour Econ. 2015;2:43-56.

36. Luo Y, Chen H, Zhu Q, Peng C, Yang G, Yang Y, et al. Relationship between air pollutants and economic development of the provincial capital cities in China during the past decade. PLoS ONE. 2014;9, e104013.

37. Rohde RA, Muller RA. Air pollution in China: mapping of concentrations and sources. PLoS ONE. 2015;10, e0135749. Overview of current air pollution distribution across China.
38. Fu C, Wu J, Gao Y, Zhao D, Han Z. Consecutive extreme visibility events in China during 1960-2009. Atmos Environ. 2013;68:1-7.

39. Reuter M, Buchwitz M, Hilboll A, Richter A, Schneising O, Hilker M, et al. Decreasing emissions of $\mathrm{NO}_{\mathrm{x}}$ relative to $\mathrm{CO}_{2}$ in East Asia inferred from satellite observations. Nat Geosci. 2014;7: 792-5.

40. Jin X, Holloway T. Spatial and temporal variability of ozone sensitivity over China observed from the Ozone Monitoring Instrument. J Geophys Res Atmos. 2015;120:7229-46.

41. Tao M, Chen L, Wang Z, Ma P, Tao J, Jia S. A study of urban pollution and haze clouds over northern China during the dusty season based on satellite and surface observations. Atmos Environ. 2014;82:183-92.

42. Zhang L, Wang T, Lv M, Zhang Q. On the severe haze in Beijing during January 2013: unraveling the effects of meteorological anomalies with WRF-Chem. Atmos Environ. 2015;104:11-21.

43. Wang Q, Zhuang G, Huang K, Liu T, Deng C, Xu J, et al. Probing the severe haze pollution in three typical regions of China: characteristics, sources and regional impacts. Atmos Environ. $2015 ; 120: 76-88$

44. Zhang Q, Yuan B, Shao M, Wang X, Lu S, Lu K, et al. Variations of ground-level $\mathrm{O}_{3}$ and its precursors in Beijing in summertime between 2005 and 2011. Atmos Chem Phys. 2014;14:6089-101.

45. Jacobson MZ, Nghiem SV, Sorichetta A, Whitney N. Ring of impact from the mega-urbanization of Beijing between 2000 and 2009. J Geophys Res Atmos. 2015;120:5740-56.

46. Zhao H, Wang S, Wang W, Liu R, Zhou B. Investigation of ground-level ozone and high-pollution episodes in a megacity of Eastern China. PLoS ONE. 2015;10, e0131878.

47. Tie X, Geng F, Guenther A, Cao J, Greenberg J, Zhang R, et al. Megacity impacts on regional ozone formation: observations and WRF-Chem modeling for the MIRAGE-Shanghai field campaign. Atmos Chem Phys. 2013;13:5655-69.

48. Guttikunda SK, Goel R, Pant P. Nature of air pollution, emission sources, and management in the Indian cities. Atmos Environ. 2014;95:501-10. Overview of air pollution sources in India.

49. Guttikunda SK, Jawahar P. Atmospheric emissions and pollution from the coal-fired thermal power plants in India. Atmos Environ. 2014;92:449-60.

50. Kumar R, Barth MC, Pfister GG, Nair VS, Ghude SD, Ojha N. What controls the seasonal cycle of black carbon aerosols in India? J Geophys Res Atmos. 2015;120:7788-812.

51. Burney J, Ramanathan V. Recent climate and air pollution impacts on Indian agriculture. Proc Natl Acad Sci U S A. 2014;111: 16319-24.

52. Tiwari S, Bisht DS, Srivastava AK, Shivashankara GP, Kumar R. Interannual and intraseasonal variability in fine mode particles over Delhi: influence of meteorology. Adv Meteorol. 2013;2013: $1-9$.

53. Guttikunda SK, Goel R. Health impacts of particulate pollution in a megacity—Delhi, India. Environ Dev. 2013;6:8-20.

54. Marrapu P, Cheng Y, Beig G, Sahu S, Srinivas R, Carmichael GR. Air quality in Delhi during the Commonwealth games. Atmos Chem Phys. 2014;14:10619-30.

55. Tiwari S, Bisht DS, Srivastava AK, Gustafsson O. Simultaneous measurements of black carbon and $\mathrm{PM}_{2.5}, \mathrm{CO}$, and $\mathrm{NO}_{\mathrm{x}}$ variability at a locally polluted urban location in India. Nat Hazards. 2014;75:813-29.

56. Pommier M, McLinden CA, Deeter M. Relative changes in $\mathrm{CO}$ emissions over megacities based on observations from space. Geophys Res Lett. 2013;40:3766-71.

57. Mamun MI, Islam M, Mondol PK. The seasonal variability of aerosol optical depth over Bangladesh based on satellite data and HYSPLIT model. Am J Remote Sens. 2014;2:20-9. 
58. Islam MM, Mamun MMI, Rasel AH, Keramat M. Pattern analysis of trace gases over Bangladesh using satellite remote sensing. Int J Remote Sens. 2015;36:3979-96.

59. Begum BA, Hopke PK, Markwitz A. Air pollution by fine particulate matter in Bangladesh. Atmos Pollut Res. 2013;4:75-86.

60. Begum BA, Nasiruddin M, Randal S, Sivertsen B, Hopke PK. Identification and apportionment of sources from air particulate matter at urban environments in Bangladesh. Br J Appl Sci Technol. 2014;4:3930-55.

61. Guttikunda SK, Khaliquzzaman M. Health benefits of adapting cleaner brick manufacturing technologies in Dhaka, Bangladesh. Air Qual Atmos Health. 2013;7:103-12.

62. Ahmed D, Zubair A, Begum A, Khan MU. Investigation and evaluation of ambient air quality in various parts of Karachi Metropolitan City, Pakistan. Midd East J Sci Res. 2014;21: 234-43.

63. Lelieveld J, Beirle S, Hormann C, Stenchikov G, Wagner T. Abrupt recent trend changes in atmospheric nitrogen dioxide over the Middle East. Sci Adv. 2015;1, e1500498.

64. Lelieveld J, Hadjinicolaou P, Kostopoulou E, Giannakopoulos C, Pozzer A, Tanarhte M, et al. Model projected heat extremes and air pollution in the eastern Mediterranean and Middle East in the twenty-first century. Reg Environ Chang. 2013;14:1937-49.

65. Komolafe AA, Adegboyega SA, Anifowose AYB, Akinluyi FO, Awoniran DR. Air pollution and climate change in Lagos, Nigeria: needs for proactive approaches to risk management and adaptation. Am J Environ Sci. 2014;10:412-23.

66. Lei W, Li G, Molina LT. Modeling the impacts of biomass burning on air quality in and around Mexico City. Atmos Chem Phys. 2013;13:2299-319.

67. Garzón JP, Huertas JI, Magaña M, Huertas ME, Cárdenas B, Watanabe T, et al. Volatile organic compounds in the atmosphere of Mexico City. Atmos Environ. 2015;119:415-29.

68. Shields KN, Cavallari JM, Hunt MJ, Lazo M, Molina M, Molina $\mathrm{L}$, et al. Traffic-related air pollution exposures and changes in heart rate variability in Mexico City: a panel study. Environ Health. 2013;12.

69. Arceo E, Hanna R, Oliva P. Does the effect of pollution on infant mortality differ between developing and developed countries? Evidence from Mexico City. Econ J. In Press. doi: 10.1111/ecoj. 12273.

70. Pérez-Martínez PJ, de Fatima Andrade M, de Miranda RM. Traffic-related air quality trends in São Paulo, Brazil. J Geophys Res Atmos. 2015;120:6290-304.

71. Reddington CL, Butt EW, Ridley DA, Artaxo P, Morgan WT, Coe $\mathrm{H}$, et al. Air quality and human health improvements from reductions in deforestation-related fire in Brazil. Nat Geosci. 2015;8: 768-71.

72. Matte TD, Ross Z, Kheirbek I, Eisl H, Johnson S, Gorczynski JE, et al. Monitoring intraurban spatial patterns of multiple combustion air pollutants in New York City: design and implementation. J Expo Sci Environ Epidemiol. 2013;23:223-31.

73. Pollack IB, Ryerson TB, Trainer M, Neuman JA, Roberts JM, Parrish DD. Trends in ozone, its precursors, and related secondary oxidation products in Los Angeles, California: a synthesis of measurements from 1960 to 2010. J Geophys Res Atmos. 2013;118: 5893-911.

74. Borbon A, Gilman JB, Kuster WC, Grand N, Chevaillier S, Colomb A, et al. Emission ratios of anthropogenic volatile organic compounds in northern mid-latitude megacities: observations versus emission inventories in Los Angeles and Paris. J Geophys Res Atmos. 2013;118:2041-57.

75. Fountoukis C, Megaritis AG, Skyllakou K, Charalampidis PE, Denier van der Gon HAC, Crippa M, et al. Simulating the formation of carbonaceous aerosol in a European Megacity (Paris) during the MEGAPOLI summer and winter campaigns. Atmos Chem Phys Discuss. 2015;15:25547-82.

76. Beekmann M, Prévôt ASH, Drewnick F, Sciare J, Pandis SN, Denier van der Gon HAC, et al. In-situ, satellite measurement and model evidence for a dominant regional contribution to fine particulate matter levels in the Paris Megacity. Atmos Chem Phys. 2015;15:9577-91.

77. Popovicheva O, Kistler M, Kireeva E, Persiantseva N, Timofeev M, Kopeikin V, et al. Physicochemical characterization of smoke aerosol during large-scale wildfires: extreme event of August 2010 in Moscow. Atmos Environ. 2014;96:405-14.

78. Thompson TM, Rausch S, Saari RK, Selin NE. A systems approach to evaluating the air quality co-benefits of US carbon policies. Nat Clim Chang. 2014;4:917-23.

79. West JJ, Smith SJ, Silva RA, Naik V, Zhang Y, Adelman Z, et al. Co-benefits of mitigating global greenhouse gas emissions for future air quality and human health. Nat Clim Chang. 2013;3:885-9.

80. Smith SJ, Mizrahi A. Near-term climate mitigation by short-lived forcers. Proc Natl Acad Sci U S A. 2013;110:14202-6.

81. Stohl A, Aamaas B, Amann M, Baker LH, Bellouin N, Berntsen TK, et al. Evaluating the climate and air quality impacts of shortlived pollutants. Atmos Chem Phys. 2015;15:10529-66.

82. Fann N, Nolte CG, Dolwick P, Spero TL, Brown AC, Phillips S, et al. The geographic distribution and economic value of climate change-related ozone health impacts in the United States in 2030. J Air Waste Manag Assoc. 2015;65:570-80.

83. Trail M, Tsimpidi AP, Liu P, Tsigaridis K, Rudokas J, Miller P, et al. Sensitivity of air quality to potential future climate change and emissions in the United States and major cities. Atmos Environ. 2014;94:552-63.

84. Horton DE, Skinner CB, Singh D, Diffenbaugh NS. Occurrence and persistence of future atmospheric stagnation events. Nat Clim Chang. 2014;4:698-703.

85. Fiore AM, Naik V, Leibensperger EM. Air quality and climate connections. J Air Waste Manage Assoc. 2015;65:645-85.

86. Baklanov A, Molina LT, Gauss M. Megacities, air quality and climate. Atmos Environ. 2016;126:235-49.

87. Cassiani M, Stohl A, Eckhardt S. The dispersion characteristics of air pollution from the world's megacities. Atmos Chem Phys. 2013;13:9975-96.

88. Anenberg SC, West JJ, Yu H, Chin M, Schulz M, Bergmann D, et al. Impacts of intercontinental transport of anthropogenic fine particulate matter on human mortality. Air Qual Atmos Health. 2014;7:369-79.

89. Kim PS, Jacob DJ, Mickley LJ, Koplitz SN, Marlier ME, DeFries RS, et al. Sensitivity of population smoke exposure to fire locations in Equatorial Asia. Atmos Environ. 2015;102:11-7.

90. Lee JSH, Jaafar Z, Tan AKJ, Carrasco LR, Ewing JJ, Bickford DP, et al. Toward clearer skies: challenges in regulating transboundary haze in Southeast Asia. Environ Sci Pol. 2016;55:87-95.

91. Greenstone M, Hanna R. Environmental regulations, air and water pollution, and infant mortality in India. Am Econ Rev. 2014;104: 3038-72.

92.•• Duflo E, Greenstone M, Pande R, Ryan N. Truth-telling by thirdparty auditors and the response of polluting firms: experimental evidence from India. Q J Econ. 2013;128:1499-545. Presents an easily implementable policy that leads to large improvements in environmental quality and reduces corruption, particularly important for settings with high pollution and weak institutions.

93. Viard VB, Fu S. The effect of Beijing's driving restrictions on pollution and economic activity. J Public Econ. 2015;125:98-115.

94. Goel D, Gupta S. The effect of metro rail on air pollution in Delhi. World Bank Econ Rev. 2015. doi: 10.1093/wber/lhv056.

95. Deschenes O, Greenstone M, Shapiro JS. Defensive investments and the demand for air quality: evidence from the 
NOx budget program and ozone reduction. NBER Working Paper No. 18267. 2012.

96. Zheng S, Sun C, Kahn ME. Self-protection investment exacerbates air pollution exposure inequality in urban China. NBER Working Paper No. 21301. 2015.

97. Chen Y, Ebenstein A, Greenstone M, Li H. Evidence on the impact of sustained exposure to air pollution on life expectancy from China's Huai River policy. Proc Natl Acad Sci U S A. 2013;110: 12936-41.

98. Cesur R, Tekin E, Ulker A. Air pollution and infant mortality: evidence from the expansion of natural gas infrastructure. Econ J. 2015. doi: 10.1111/ecoj.12285.

99. Heutel G, Ruhm CJ. Air pollution and procyclical mortality. NBER Working Paper No. 18959. 2013.
100. Rao S, Pachauri S, Dentener F, Kinney P, Klimont Z, Riahi K, et al. Better air for better health: forging synergies in policies for energy access, climate change and air pollution. Glob Environ Chang. 2013;1122-30.

101. Ford B, Heald CL. Exploring the uncertainty associated with satellite-based estimates of premature mortality due to exposure to fine particulate matter. Atmos Chem Phys Discuss. 2015;15: 25329-80.

102. Pope III CA, Cropper M, Coggins J, Cohen A. Health benefits of air pollution abatement policy: role of the shape of the concentrationresponse function. J Air Waste Manag Assoc. 2015;65:516-22.

103. Ru M, Tao S, Smith K, Shen G, Shen H, Huang Y, et al. Direct energy consumption associated emissions by rural-to-urban migrants in Beijing. Environ Sci Technol. 2015;49:13708-15. 